\title{
Dietary patterns and significance of nutrition for women with low-risk pregnancy
}

\section{Padrões alimentares e significados da alimentação de gestantes}

de baixo risco

Natália Sales de CARVALHO

Soraia Pinheiro Machado ARRUDA²

Letícia Maria Rodrigues RAMOS 3

Marcia Maria Tavares MACHADO 4

Daniela Vasconcelos de AZEVEDO²

\section{A B S T R A C T}

\section{Objective}

To evaluate dietary patterns and significance of diet for pregnant women.

\section{Methods}

Cross-sectional study carried out in eight health units in Fortaleza, Ceará, Brazil, with 201 pregnant women. The following instruments were used: a socio-economic and health questionnaire, the Free-Word Association Test, and a Food Frequency Questionnaire. Dietary patterns were identified using principal components and factor analysis. Poisson regression with $5 \%$ significance level was used.

\section{Results}

Three dietary patterns were identified: current Brazilian pattern (beans, rice, processed meats, fats, refined grains, pasta and pastries, soft drink, sugar and sweets, cookies and crackers); healthy pattern (fruits and fruit juices, vegetables, whole grains, seafood, dairy products); and energy-rich pattern (salty deep-fried snacks,

1 Universidade de Fortaleza, Centro de Ciências da Saúde, Curso de Nutrição. Av. Washington Soares, 1321, Edson Queiroz, 60811-905 Fortaleza, CE, Brasil. Correspondência para/Correspondence to: NS CARVALHO. E-mail: <natycarvalho_@hotmail.com>.

${ }^{2}$ Universidade Estadual do Ceará, Centro de Ciências da Saúde, Programa de Pós-Graduação em Nutrição e Saúde.

3 Universidade Estadual do Ceará, Centro de Ciências da Saúde, Curso de Nutrição. Fortaleza, CE, Brasil.

${ }^{4}$ Universidade Federal do Ceará, Pró-Reitoria de Extensão, Programa de Pós-Graduação em Associação e do Mestrado em Saúde Pública. Fortaleza, CE, Brasil.

Article based on the masther's thesis of NS CARVALHO, intitled "Alimentação de gestantes atendidas na atenção primária: significados, padrões alimentares e aspectos socioeconômicos". Universidade Estadual do Ceará; 2015. 
popcorn, packaged snacks, instant noodles, tubers, and chicken). Women who did not receive nutrition guidance during prenatal care showed less chance of adherence to the current Brazilian dietary pattern $(P R=0.87)$, and therefore their level of consumption of foods commonly present in Brazilian diets was low. For most women, the significance of diet was reported as important and healthy, but it was not associated with any of the diet patterns identified. However, the women who did not consider that during pregnancy diet should be healthy showed greater chance of adherence to the energy-rich pattern ( $P R=1.18)$. This finding deserves special attention since excessive weight gain can have a negative effect on pregnancy.

\section{Conclusion}

Nutrition guidance during prenatal care and the way pregnant women perceive their eating habits can influence their food choices during pregnancy.

Keywords: Feeding behavior. Pregnant women. Prenatal care.

\section{R E S U M O}

\section{Objetivo}

Avaliar o padrão alimentar e os significados que a alimentação tem para gestantes.

\section{Métodos}

Estudo transversal em oito unidades de saúde de Fortaleza, Ceará, com 201 gestantes. Utilizou-se questionário socioeconômico e de saúde, Teste de Associação Livre de Palavras e Questionário de Frequência Alimentar. Os padrões alimentares foram identificados pelo método de análise fatorial por componentes principais. Utilizou-se a regressão de Poisson, adotando-se nível de significância de 5\%.

\section{Resultados}

Três padrões alimentares foram identificados: brasileiro atual (feijão, arroz, carnes processadas, gorduras, pães refinados, massas, refrigerante, açúcares e doces, biscoitos), saudável (frutas e sucos de frutas, vegetais, cereais integrais, frutos do mar, laticínios) e denso em energia (salgados, pipoca, salgadinho, macarrão instantâneo, tubérculos e frango). As mulheres que não receberam orientação sobre alimentação no pré-natal mostraram menor chance de aderir ao padrão brasileiro atual $(R P=0.87)$, o que fez com que alimentos típicos da dieta do brasileiro fossem pouco consumidos entre elas. Para a maioria das mulheres, o significado da alimentação foi ser importante e saudável, porém representar esses significados não mostrou associação com nenhum dos padrões alimentares identificados. No entanto, aquelas que não perceberam a alimentação como algo que deve ser saudável apresentaram maior chance de adesão ao padrão denso em energia $(R P=1.18)$, padrão que deve ser visto com cuidado, pois o ganho de peso excessivo pode repercutir negativamente na gravidez.

\section{Conclusão}

As orientações alimentares no pré-natal e o modo como as gestantes percebem sua alimentação podem influenciar nas escolhas alimentares na gravidez.

Palavras-chave: Comportamento alimentar. Gestantes. Pré-natal.

\section{INTRODUCTION}

\section{Nutritional care during pregnancy} contributes to an adequate nutritional status preventing negative impacts on maternal and infant health resulting from low or excess body weight [1-3]. In order to ensure an adequate pregnancy monitoring, prenatal care should begin during the first trimester, i.e., before completing 13 weeks of pregnancy. It is important to emphasize that not only is early prenatal care important, but regular care is just as fundamental. For women with low-risk pregnancy, attending all prenatal visits provides greater opportunity to monitor maternal weight gain and undertake educational activities [4]. Among these activities is food and nutrition education, which can help pregnant women adopt healthy eating habits [5].

Moreover, with regard to food consumption during pregnancy, psychological and 
emotional aspects must be taken into account since they can also influence food choices $[6,7]$. However, few studies have investigated pregnant women's perception of pregnancy-related phenomena and their significance for those women [8].

Nutritional interventions considering symbolic representations of eating and how they can influence dietary patterns can contribute to prenatal care because such knowledge can be useful when adopting strategies to offer a nutritional guidance that corresponds to these women reality [9].

After collecting data by dietary instruments, the analysis of food consumption can be carried out using different methods, such as the dietary pattern. The assessment of eating habits using patterns emerged as an alternative method in nutritional epidemiology and is justified by the fact that people do not eat certain foods or nutrients in isolation but rather in combination during meals $[10,11]$. The analysis of patterns of food intake during pregnancy has been widely used, as shown in the studies carried out by Brantsaeter et al. [1], Uusitalo et al. [2], Gaillard et al. [3], among others.

Thus, due to the complexity of factors that can influence food choices of individuals, this study aimed to investigate the dietary patterns and significance of nutrition for pregnant women receiving care in primary health care units.

\section{METHODS}

The present study has a cross-sectional design and a combined quantitative and qualitative approach. It was carried out in eight health care facilities in the city of Fortaleza, Ceará, Brazil, which were selected to represent the six Regional Health Departments of Fortaleza. The sample of this study was selected by convenience using non-probability sampling. All pregnant women $>19$ years who attended their regular prenatal visit at the health care facilities on the days of data collection between April and November 2014 were recruited. The sample was composed of 201 pregnant women.

Data was collected using an instrument including socioeconomic variables and variables related to maternal health, the Teste de Associação Livre de Palavras (Free-Word Association Test), and a Quantitative Food Frequency Questionnaire (QFFQ). The following prenatal variables were investigated: gestational age at the beginning of prenatal care, number of prenatal visits attended, and nutrition guidance during the prenatal visits.

Free-Word Association Test is a projective technique by which the psychological structure of individuals can be demonstrated and perceived by their reactions, evocation, or choice of the respondents [12]. In addition to being flexible, fast, and easy to understand for the participants, it is a method that can be adapted to different research purposes. It can be applied alone or combined with other classical methods, such as interview and questionnaire [13]. This technique consists of asking participants to immediately speak or write words or phrases that come to mind after hearing a particular inducing stimulus, which can be a word, or seeing a drawing or an object [12].

The word "nutrition" was used in the present study as the stimulus word, and the words with frequency 1 were discarded. A list of the evoked words was made and entered into the EVOC 2000 software for further analysis. Identical or similar words, synonyms, and words that were somewhat similar in meanings were grouped together to establish categories [14].

In order to investigate the dietary intake among the pregnant women, a QFFQ for pregnant women, developed by Oliveira et al. [15], was used. This instrument was chose due to the fact it was the only instrument validated for pregnant women in Brazil when the data were collected. Moreover, this instrument was developed with adult pregnant women of low socioeconomic status with low-risk pregnancy, 
similar to the population investigated in the present study.

The 85 food items present in the instrument plus ten other items that were included because they are mentioned in the final question of the QFFQ (question about any food they consumed frequently but was not included in the other questions), resulted in a total of 95 items. These food items were grouped into 26 food groups, according to nutritional composition similarities.

The dietary patterns were identified using factor analysis and Principal Component Analysis (PCA) following these steps: use of Kaiser-MeyerOlkin (KMO) test to measure suitability of data for factor analysis with a cut-off value $\geq 0.5$ and the Bartlett's Sphericity Test (BST), with $p \leq 0.05$; extraction of factors by defining the number of factors to retain using the eigenvalues and the Cattell's scree test (scree plot), in which the points at which the curve changes drastically (and the "scree on the hill slope" begins) indicate the maximum number of factors to retain and the subjective interpretation of the dietary patterns identified [10]; rotation of the factors retained using varimax, an orthogonal rotation method; each major component was then interpreted based on the foods with factor loadings (correlation coefficients between dietary variables and factors) $\geq 0.3$ or $\leq-0.3$; and lastly, each major component was named according to the food present in each factor $[10,16]$. It is worth mentioning that negative charges indicate an inverse correlation between the food item and the dietary pattern and positive charges indicate a direct correlation between them [17].

Each participant pregnant woman received a score for each factor that was retained. Subsequently the factor scores of each dietary pattern were categorized into quartiles; the upper quartile of the distribution represented the highest adherence to the dietary pattern. Statistical analyses were carried out using the Stata SE version 10.0 (StataCorp LLC, College Station, Texas, United States).
The analysis of the Teste de Associação Livre de Palavras (TALP, Free Word Association Test) data was carried out using the EVOC 2000 software and the frame of four houses technique based on the categories identified, which takes into account the average frequency and the Average Order of Evocations (AOE), which refer to the number of times a word was given and the order (first, second or third) in which it was given, respectively. For the purpose of the present study, only the categories with the highest frequency and lowest order of evocation were considered, i.e., the first words given by the highest number of participants, which were therefore classified as the most significant words for the group. The pregnant women were separated into 2 groups: those who evoked the words that were included in the most significant categories of the TALP and those who did not evoke such words. This allowed verifying whether there was association between the most frequent evoked meanings of the stimulus word "diet" and dietary patterns found.

Descriptive statistical analysis was carried out. The categorical variables were described in terms of simple frequencies and percentages, and the numerical variables were presented in terms of means and standard deviations. Poisson regression with robust error variance was used in the bivariate and multivariate analyses to estimate the Prevalence Ratios (PR) of the proportion of independent variables over the proportion of the outcomes. The dependent variables, i.e., the food consumption patterns, were classified as dichotomous variables: low consumption $\left(1^{\text {st }}, 2^{\text {nd }}\right.$, and $3^{\text {rd }}$ quartiles) and high consumption ( $4^{\text {th }}$ quartile).

In the multivariate analysis, the dietary patterns were associated with prenatal data: age at the beginning of prenatal care, number of prenatal visits attended, and nutrition guidance during the prenatal visits. Moreover, the categories with the highest significance for the group, according to the TALP analysis, were associated to the dietary patterns as another way to measure association. The estimates were 
determined using 95\% confidence intervals; the significance level adopted was $5 \%$.

This study was approved by the Research Ethics Committee of the Universidade Estadual do Ceará, according to the Resolution $n^{\circ} 466 / 12$ of the National Health Council (Protocol $n^{\circ}$ 388.016). This research is derived from a larger study entitled: "Maternal and infant health care network in Fortaleza: Providing care for pregnant women, nursing mothers, and children less than two years of age" (Chamada Universal 14/2013, Conselho Nacional de Desenvolvimento Científico e Tecnológico n 484077/2013-9).

\section{RES U L T S}

The median of age of the group was 25 years (19-41 years). Most of participant pregnant women had family income below or equal to two times the minimum wage (93.2\%). More than half of them had $>9$ years of formal education (51.7\%), 76.6\% lived with a partner, and $70.7 \%$ had three children or less (Table 1).

The median gestational age at the beginning of prenatal care was 12 weeks (4-30 weeks). Most participants had attended less than six prenatal visits (84.9\%) when the research was

Table 1. Socio-economic characteristics and prenatal care data of pregnant women receiving primary health care. Fortaleza (CE), Brazil (2014).

\begin{tabular}{|c|c|c|c|}
\hline Characteristics & $n$ & $\%$ & Total (n) \\
\hline Age (years) & & & $201^{*}$ \\
\hline$\leq 35$ & 187 & 93.00 & \\
\hline$>35$ & 14 & 7.00 & \\
\hline Level of education (years) & & & $201^{*}$ \\
\hline$\leq 9$ & 97 & 48.30 & \\
\hline$>9$ & 104 & 51.70 & \\
\hline Marital status & & & $201^{*}$ \\
\hline Companion & 154 & 76.60 & \\
\hline No companion & 47 & 23.40 & \\
\hline Household income (MW) & & & $191^{*}$ \\
\hline$\leq 2$ & 178 & 93.20 & \\
\hline$>3$ & 13 & 6.80 & \\
\hline Number of children & & & $201^{*}$ \\
\hline$\leq 3$ & 142 & 70.70 & \\
\hline$>3$ & 59 & 29.40 & \\
\hline Gestational age at the beginning of prenatal care (weeks) & & & $183^{*}$ \\
\hline$\leq 13$ & 109 & 59.56 & \\
\hline$>13$ & 74 & 40.44 & \\
\hline Nutrition guidance during prenatal visits & & & $200^{*}$ \\
\hline Yes & 107 & 53.50 & \\
\hline No & 93 & 46.50 & \\
\hline Number of prenatal visits when the research was conducted & & & $198^{*}$ \\
\hline$<6$ & 168 & 84.85 & \\
\hline$\geq 6$ & 30 & 15.15 & \\
\hline Pre-pregnancy weight & & & $183^{*}$ \\
\hline$\leq 75 \mathrm{~kg}$ & 152 & 83.06 & \\
\hline$>75 \mathrm{~kg}$ & 31 & 16.94 & \\
\hline Pre-pregnancy body mass index & & & $147^{*}$ \\
\hline$\leq 24.9 \mathrm{~kg} / \mathrm{m}^{2}$ & 83 & 56.46 & \\
\hline$\geq 25 \mathrm{~kg} / \mathrm{m}^{2}$ & 64 & 43.54 & \\
\hline
\end{tabular}

Note: *Variation of $n$ due to the absence of information some pregnant women.

MW: Minimum Wages: R\$724,00 (2014). 
carried out; $56.5 \%$ of the women had adequate pre-pregnancy Body Mass Index, with a median of $24 \mathrm{~kg} / \mathrm{m}^{2}\left(18-39 \mathrm{~kg} / \mathrm{m}^{2}\right)$ (Table 1$)$.

The Kaiser-Meyer-Olkin coefficient measure of sampling adequacy was 0.536, indicating appropriateness of factor analysis. Ten factors with eigenvalues $\geq 1.0$ were retained, and the inflexion on the Cattell's scree test plot indicated two factors. Based on the interpretation of the retained factors, three major dietary patterns were identified, which explained $26.0 \%$ of the total variance.

The dietary patterns Identified were named as follows: Current Brazilian pattern, characterized by the presence of beans, rice, processed meats (meat products are manufactured by the industry with the addition of salt and preservatives), fats, refined grains, rice-based preparations, pasta and pastries, soft drinks, sugar and sweets, and cookies and crackers - there was an inverse association between the current Brazilian pattern and the consumption of nuts; Healthy pattern, represented by the presence of fruits and fruit juices, leaf vegetables and other vegetables, whole grains, seafood, and dairy products - an inverse association between this pattern and coffee consumption was found; and Energy-rich pattern, represented by the presence of salty deep-fried snacks, popcorn, packaged snacks, instant noodles, tubers, and chicken - there was an inverse association between this pattern and the consumption of beans. The dietary patterns current Brazilian and energy-rich explained the greatest proportion of the total variance $(9.2 \%$ and $8.9 \%$, respectively) (Table 2 ).

Dietary patterns are commonly named by the researchers $[10,16]$; however, we searched the literature for denominations of eating patterns

Table 2. Distribution of factor loadings of the main dietary patterns identified among pregnant women receiving primary health care. Fortaleza (CE), Brazil (2014).

\begin{tabular}{|c|c|c|c|}
\hline Food groups & Current Brazilian pattern & Energy-rich pattern & Healthy pattern \\
\hline Beans & 0.62 & -0.31 & \\
\hline Rice & 0.56 & & \\
\hline Processed meat & 0.39 & & \\
\hline Fats & 0.49 & & \\
\hline Refined grains & 0.34 & & \\
\hline Rice-based preparations and pasta and pastries & 0.48 & & \\
\hline Soft drink & 0.30 & & \\
\hline Sugars and sweets & 0.50 & & \\
\hline Cookies and crackers & 0.32 & & \\
\hline Nuts & -0.30 & & \\
\hline Frits and fruit juices & & & 0.53 \\
\hline Leaf vegetables & & & 0.64 \\
\hline Other vegetable & & & 0.66 \\
\hline Whole grains & & & 0.31 \\
\hline Seafood & & & 0.34 \\
\hline Dairy products & & & 0.48 \\
\hline Coffee & & & -0.35 \\
\hline Salty deep-fried snacks & & 0.67 & \\
\hline Popcorn, packaged snacks & & 0.40 & \\
\hline Instant noodles & & 0.49 & \\
\hline Tuber & & 0.42 & \\
\hline Chicken & & 0.64 & \\
\hline Explained Variance (\%) & 9.20 & 8.90 & 7.90 \\
\hline Eigenvalue & 2.84 & -1.98 & 1.94 \\
\hline
\end{tabular}

Note: Foods with factor loadings $\geq 0.3$ or $\leq-0.3$; total variance $=26 \%$. 
with composition similar to that of the patterns in this study. The healthy pattern was found with the same name in other studies involving pregnant women with similar food group distribution $[2,18]$. The energy-rich pattern received the same name in the study carried out by Bouwland-Both et al. [19], and the name "current Brazilian pattern" is similar to that found in the study by Hoffmann [20], who used the name "commonBrazilian".

A total of 286 words were evoked by the TALP for the stimulus word "diet". The categories important and healthy had the highest frequency and the lowest order of evocation, and were therefore considered as the significance of "diet" for this group of pregnant women.

As for the prenatal data, women who did not receive nutrition guidance during pregnancy showed low adherence to the current Brazilian dietary pattern. The other variables (gestational age at the beginning of prenatal care and number of prenatal visits attended) were not associated with the dietary patterns identified (Table 3).

Table 3. Crude and adjusted Prevalence Ratios (PR) and Confidence Intervals $(95 \% \mathrm{Cl})$ for the association between the prenatal variables and the Current Brazilian, Healthy, and Energy-rich dietary patterns identified among pregnant women receiving primary health care. Fortaleza (CE), Brazil (2014).

\begin{tabular}{|c|c|c|c|c|c|c|}
\hline Current Brazilian dietary pattern & Crude PR & $p^{*}$ & $95 \% \mathrm{Cl}$ & Adjusted PR & $p^{*}$ & $95 \% \mathrm{Cl}$ \\
\hline Gestational age at the beginning of prenatal care (weeks) & & 0.666 & & & 0.271 & \\
\hline$\leq 13$ & Reference & & - & Reference & & - \\
\hline$>13$ & 0.97 & & $0.85-1.11$ & 0.93 & & $0.81-1.06$ \\
\hline Number of prenatal visits & & 0.869 & & & 0.711 & \\
\hline$<6$ & Reference & & - & Reference & & - \\
\hline$\geq 6$ & 0.98 & & $0.80-1.20$ & 0.97 & & $0.80-1.16$ \\
\hline Nutrition guidance during prenatal visits & & 0.188 & & & 0.043 & \\
\hline Yes & Reference & & - & Reference & & - \\
\hline No & 0.92 & & $0.81-1.04$ & 0.87 & & $0.77-0.99$ \\
\hline \multicolumn{7}{|l|}{ Energy-rich dietary pattern } \\
\hline Gestational age at the beginning of prenatal care (weeks) & & 0.569 & & & 0.461 & \\
\hline$\leq 13$ & Reference & & - & Reference & & - \\
\hline$>13$ & 1.04 & & $0.91-1.20$ & 1.06 & & $0.91-1.24$ \\
\hline Number of prenatal visits & & 0.190 & & & 0.457 & \\
\hline$<6$ & Reference & & - & Reference & & - \\
\hline$\geq 6$ & 0.87 & & $0.71-1.07$ & 0.92 & & $0.73-1.15$ \\
\hline Nutrition guidance during prenatal visits & & 0.703 & & & 0.687 & \\
\hline Yes & Reference & & - & Reference & & - \\
\hline No & 1.03 & & $0.90-1.17$ & 1.03 & & $0.89-1.19$ \\
\hline \multicolumn{7}{|l|}{ Healthy dietary pattern } \\
\hline Gestational age at the beginning of prenatal care (weeks) & & 0.521 & & & 0.339 & \\
\hline$\leq 13$ & Reference & & - & Reference & & - \\
\hline$>13$ & 0.96 & & $0.83-1.10$ & 0.93 & & $0.80-1.08$ \\
\hline Number of prenatal visits & & 0.269 & & & 0.526 & \\
\hline$<6$ & Reference & & - & Reference & & - \\
\hline$\geq 6$ & 1.11 & & $0.93-1.32$ & 1.06 & & $0.88-1.28$ \\
\hline Nutrition guidance during prenatal visits & & 0.472 & & & 0.292 & \\
\hline Yes & Reference & & - & Reference & & - \\
\hline No & 0.95 & & $0.84-1.08$ & 0.93 & & $0.81-1.06$ \\
\hline
\end{tabular}

Note: * $p$-value refers to the maximum likelihood (likelihood ratio test) obtained by Poisson regression. Adjusted for the variables: age, level of education, marital status, and household income. 
Table 4. Crude and adjusted Prevalence Ratios (PR) and $95 \%$ Confidence Intervals (95\% Cl) for the association between the TALP and the Current Brazilian, Healthy, and Energy-rich dietary patterns identified among pregnant women receiving primary health care. Fortaleza (CE), Brazil (2014).

\begin{tabular}{|c|c|c|c|c|c|c|}
\hline Current Brazilian dietary pattern & Crude PR & $p^{*}$ & $95 \% \mathrm{Cl}$ & Adjusted PR & $p^{*}$ & $95 \% \mathrm{Cl}$ \\
\hline TALP - central category: Healthy & & 0.275 & & & 0.635 & \\
\hline Yes & Reference & & - & Reference & & - \\
\hline No & 1.09 & & $0.94-1.27$ & 1.04 & & $0.90-1.20$ \\
\hline TALP - central category: Important & & 0.414 & & & 0.226 & \\
\hline Yes & Reference & & - & Reference & & - \\
\hline No & 0.91 & & $0.73-1.14$ & 0.89 & & $0.73-1.08$ \\
\hline \multicolumn{7}{|l|}{ Energy-rich dietary pattern } \\
\hline TALP - central category: Healthy & & 0.070 & & & 0.032 & \\
\hline Yes & Reference & & - & Reference & & - \\
\hline No & 1.15 & & $0.99-1.33$ & 1.18 & & $1.01-1.38$ \\
\hline TALP - central category: Important & & 0.445 & & & 0.539 & \\
\hline Yes & Reference & & - & Reference & & - \\
\hline No & 1.09 & & $0.87-1.38$ & 1.08 & & $0.84-1.39$ \\
\hline \multicolumn{7}{|l|}{ Healthy dietary pattern } \\
\hline TALP - central category: Healthy & & 0.242 & & & 0.680 & \\
\hline Yes & Reference & & - & Reference & & \\
\hline No & 0.92 & & $0.81-1.06$ & 0.97 & & - \\
\hline TALP - central category: Important & & 0.289 & & & 0.302 & $0.85-1.11$ \\
\hline Yes & Reference & & - & Reference & & - \\
\hline No & 0,89 & & $0.72-1.10$ & 0.90 & & $0.73-1.10$ \\
\hline
\end{tabular}

Note: " $p$-value refers to the maximum likelihood (likelihood ratio test) obtained by Poisson regression. Adjusted for the variables: age, level of education, marital status, and household income.

TALP: Teste de Associação Livre de Palavras (Free-Word Association Test).

There was no association between the significance of "nutrition" (healthy and important) and any of the food patterns for the women studied. However, not evoking words related to the healthy category showed greater adherence to the energy-rich dietary pattern (Table 4).

\section{DISCUSSION}

Three major dietary patterns were identified among the pregnant women investigated: current Brazilian, healthy, and energy-rich. Women who did not receive nutrition guidance during pregnancy showed low adherence to the current Brazilian pattern and not evoking words related to the healthy category showed greater adherence to the energy-rich dietary pattern.
The current Brazilian dietary pattern is composed of staple foods of the standard Brazilian diet, as can be evidenced by the presence of rice, beans, processed meats (encased meats (sausage) and bacon), fats (butter and margarine), refined grains, soft drinks, sugars and sweets, and cookies and crackers. According to the Pesquisa de Orçamentos Familiares (POF, Family Budget Survey) - which is conducted every five years in Brazil to obtain general information about households, families, people, and consumption habits among others - rice, beans, beef, juices, soft drinks, and coffee show the highest average consumption in Brazilian households [21].

This dietary pattern combines the traditional Brazilian diet, which is based on the important nutritional combination of rice and beans, with the inclusion of processed foods that are rich in sugar, sodium, fats and that are high 
in calories [21]. Processed foods did not use to be included in the Brazilian diet, but nowadays their presence has been increasingly recognized. It is worth mentioning that nuts, which are rich in protein and heart-healthy fats, showed an inverse association with the current Brazilian dietary pattern.

A study conducted with pregnant women from the Southern region in Brazil identified a dietary pattern denominated "common-Brazilian" that is similar to the current Brazilian pattern identified in the present study, and it was characterized by traditional and popular Brazilian foods such as white rice, beans, pasta, French bread, beef, chicken, eggs, margarine, coffee, artificial juice, and sugar [20]. The current Brazilian pattern differs from that pattern because it includes foods such as soft drinks, processed meats, and cookies and crackers and does include chicken, eggs, coffee, and artificial juices.

In Brazil, there has been a tendency to replace traditional meals based on in natura or minimally processed foods with ultra-processed foods, as reported by de Louzada et al. [22], using the 2008-2009 POF data. Additionally, assessing the impact of consumption of ultra-processed foods, these authors found that the nutritional profile of these foods showed that they have higher contents of energy, fat, and sugar and have lower fiber content compared to those of in natura or minimally processed foods.

The healthy dietary pattern (fruits and fruit juices, leaf vegetables and other vegetables, whole grains, seafood, and dairy products) is represented by foods rich in fiber, vitamins, and minerals; which are essential for healthy fetal growth and development and can protect maternal health [1]. Coffee showed negative factor loadings for this pattern. Excessive caffeine intake during pregnancy has been associated with premature birth, low birth weight, and miscarriage. However, for these effects to take place, a very high daily intake of caffeine would be necessary, which is unlikely; therefore, there is still controversy regarding caffeine restriction and consumption during pregnancy [23].
A dietary pattern denominated healthy was identified in other studies involving pregnant women and with similar food group distribution $[2,18]$. In some studies, similar patterns were found with different names, such as "vegetable" [1] "health conscious" [24] and "prudent" $[25,26]$.

The energy-rich pattern (salty deep-fried snacks, popcorn, packaged snacks, instant noodles, tubers, and chicken) was composed mainly of processed foods, which are often high in sodium and fat [21]. Frequent and high intake of these foods increases the risk of complications during pregnancy, such as excess weight, obesity, and high blood pressure $[1,2]$. It was also found that the intake of beans, an important food during pregnancy due to its high nutritional value, was inversely associated with the energy-rich pattern.

The dietary patterns of pregnant women denominated in other studies as "processed food" and $[1,24]$ "high-energy diet" [26] are similar the energy-rich pattern identified in the present study because they are composed of processed foods that are often high in sodium and fat despite the great variety of foods present in those patterns. An example is the "processed food" pattern reported in the study by Brantsaeter et al. [1], which was characterized by the presence of processed meats, refined grains, sugar-sweetened drinks, sweets, pasta and pastries, sauces, fish, cereals, packaged snacks, and popcorn. The energy-rich pattern reported in the study by Bouwland-Both et al. [19] was characterized by the presence of food such as bread, breakfast cereals, margarine, nuts, sweets, and non-alcoholic drinks, a little different composition from that of the pattern of the present study although having the same denomination. This can be justified by the different methodologies used in each one of those studies due to the subjectivity involved in some steps of the factor analysis to reduce the factors, including the criteria used to determine the number of factors to extract and the labeling of the dietary patterns, which is also chosen by the researchers $[10,16,27]$. 
In the present study, the women who did not receive nutritional guidance during pregnancy showed low adherence to the current Brazilian pattern. Since this pattern combines foods traditionally consumed by Brazilian families and processed and ultra-processed foods [21,22], it should be considered with caution, especially by pregnant women. However, the consumption of this dietary pattern should not be discouraged but guided, aiming at better choices of the foods that compose this pattern.

The lack of nutritional guidance during pregnancy can lead pregnant women to make unhealthy choices. This may be due to doubts or food taboos related to child health protection that they may have, but which can affect their nutritional status [5].

Prenatal visits should be used as an opportunity to carry out nutrition education activities that can help pregnant women, especially those who began their pregnancy with an inadequate nutritional status, adopt healthier eating habits, promoting proper pregnancy progress thus reducing the chances of maternal and infant complications [2,3]. This may also lead to decreased risk of childhood obesity, respiratory diseases, high blood pressure, dyslipidemia, and other health problems [3,25].

Vitolo et al. [5] investigated the impact of nutrition guidance on the control of weight gain during pregnancy. Their results showed that the guidance provided was effective in reducing pregnancy weight gain in overweight women and also in minimizing adverse clinical events resulting from such inadequate nutritional status, such as gestational diabetes, preeclampsia, low birth weight, and prematurity.

It is expected that the earlier the prenatal visits start, the greater the opportunities for health care professionals to provide nutritional counseling. In this study, a little more than half of the pregnant women began prenatal care during the first trimester of pregnancy (Table 1), as recommended by the "Ministry of Health". They reported receiving nutrition guidance during their prenatal visits; these findings may support nutritional interventions programs during pregnancy. However, it is worth highlighting that gestational age at the beginning of prenatal care and receiving nutritional guidance were not associated with any of the dietary patterns identified in the study.

The significance of nutrition for the pregnant women was that it should be healthy and that is important for their own health as their baby' health. Their perception of the relationship between greater attention to their food intake and proper development of the baby has also been reported in other studies $[7,28]$.

The participant pregnant women recognized that the food they consume affect fetal growth; thus, they believe that their baby health and weight depend on their eating habits and that therefore making healthier food choices is essential [7]. However, although the significance of diet for these women was reported as important and healthy, it was not associated with any of the identified food patterns. It is unclear whether the women who recognized and reported the importance of a healthy diet actually adopt healthier eating behaviors. However, the pregnant women who did not evoke words included in the healthy category, i.e., those who did not seem to realize the importance of healthy eating, showed greater adherence to the energyrich dietary pattern. Nevertheless, the adherence to this pattern should be considered with caution because of the consequences of excessive weight gain during pregnancy [3].

Baião \& Deslandes [29] found that when pregnant women were asked about their eating habits, they mentioned foods that they believed to be healthy, but those were not necessarily the foods they consumed, which shows the influence of scientific discourse and the difficulty of putting it into practice. Therefore, it can be said that recognizing the importance and benefits of an adequate and healthy diet does not guarantee its adoption [28]. 
Eating habits involve several socioeconomic and cultural factors, and thus making healthy food choices on a daily basis is not an easy task $[9,6]$. Moreover, when pregnant women do not even realize that they should adopt a healthy diet during pregnancy, they tend to maintain unhealthy habits and consume foods high in energy, fat, and sodium, such as the case of adherence to the energy-rich pattern. Therefore, it is necessary to reinforce the importance of providing nutritional guidance to those women because, although they are not always effective, the lack of guidance can stimulate inappropriate eating $[5,17,28]$.

Understanding the nutrition of pregnant women in a more comprehensive way, encompassing the many variables that influence their eating behavior, such as the variables related to prenatal care, and the significance of diet for these women, can contribute to more effective and efficient nutritional intervention actions, improving nutrition during pregnancy.

One limitation of the present study is the use of a food frequency questionnaire validated for pregnant women from another region of the country since that there is no FFQ validated for pregnant women from the Northeastern region available. The FFQ used was chosen for being an instrument that allows the inclusion of other foods that are not included in the questionnaire but are often consumed by pregnant women. Another reason is that this FFQ was validated for pregnant women of low socio-economic status with low-risk pregnancy, population that is similar to that in our study. Moreover, the frequency of consumption was assessed and not the serving size since the latter could be different between the groups of pregnant women investigated. Other limitations are related to the use of factor analysis because of the subjectivity involved in the several steps to reduce the factors, including the criteria used to determine the number of factors to extract and the labeling of the dietary patterns, which is also chosen by the researchers. In order to minimize these issues, the choices made were described in detail $[10,16]$.
In addition to the efforts to overcome the limitations mentioned above, a positive and significant contribution of this study is the fact that there are no other studies available investigating the significance of diet for pregnant women and associating it with dietary patterns, highlighting the importance of the methodology used.

\section{CONCLUSION}

Three dietary patterns were identified among pregnant women with low-risk pregnancy: current Brazilian, healthy, and energy-rich. The significance of diet for the pregnant women investigated was that it is important and should be healthy. Nutrition guidance during prenatal care and the way pregnant women perceive their eating habits can influence their food choices during pregnancy. This fact requires special attention of health care professionals providing prenatal care. Further studies are necessary to investigate the nutrition guidance and education provided by health care professionals to this public.

\section{A KNOWLEDGEMENTS}

The authors NS CARVALHO and DV AZEVEDO contributed to study conception and design, and data analysis and interpretation. The authors LMR RAMOS, SPM ARRUDA and MMT MACHADO to data analysis and interpretation.

\section{REFERENCES}

1. Brantsaeter AL, Haugen M, Samuelsen SO, Torjusen $\mathrm{H}$, Trogstad L, Alexander J, et al. A dietary pattern characterized by high intake of vegetables, fruits, and vegetable oils is associated with reduced risk of preeclampsia in nulliparous pregnant Norwegian women. J Nutr. 2009;139(6):1662-8. https://doi. org/10.3945/jn.109.104968

2. Uusitalo U, Arkkola T, Ovaskainen M, KronbergKippila C, Kenward MG, Veijola R, et al. Unhealthy dietary patterns are associated with weight gain during pregnancy among Finnish women. Public 
Health Nutr. 2009;12(12):2392-99. https://doi.org/ 10.1017/S136898000900528X

3. Gaillard R, Felix JF, Duijts L, Jaddoe VWV. Childhood consequences of maternal obesity and excessive weight gain during pregnancy. Acta Obstet Gynecol Scand. 2014; 93(11):1085-9. https://doi.org/10. 1111/aogs. 12506

4. Ministério da Saúde (Brasil). Atenção ao pré-natal de baixo risco. Cadernos de Atenção Básica. 2012 [acesso 2015 set 18];(32). Disponível em: http:// bvsms.saude.gov.br/bvs/publicacoes/cadernos_ atencao_basica_32_prenatal.pdf

5. Vitolo MR, Bueno MSF, Gama CM. Impacto de um programa de orientação dietética sobre a velocidade de ganho de peso de gestantes atendidas em unidades de saúde. Rev Bras Ginecol Obstet. 2011;33(1):13-9.

6. Bayley TM, Dye L, Jones S, Bono MD, Hill AJ. Food cravings and aversions during pregnancy: Relationships with nausea and vomiting. Appetite. 2002;38(1):45-5.

7. Junges CF, Ressel LB, Monticelli M. Entre desejos e possibilidades: práticas alimentares de gestantes em uma comunidade urbana no Sul do Brasil. Texto Contexto Enferm. 2014; 23(2):382-90. https://doi. org/10.1590/0104-07072014000210013

8. Azevedo DV, Araújo ACPF, Costa ICC. An analysis of the meanings of pre-eclampsia for pregnant and postpartum women and health professionals in Rio Grande do Norte, Brazil. Midwifery. 2010;27(6):182-7. https://doi.org/10.1016/j.midw.2010.06.021

9. Garcia RWD. Representações sobre consumo alimentar e suas implicações em inquéritos alimentares: estudo qualitativo em sujeitos submetidos à prescrição dietética. Rev Nutr. 2004;17(1):15-28. https//:doi.org/10.1590/S1415-52732004000 100002

10. Newby PK, Tucker KL. Empirically derived eating patterns using factor or cluster analysis: A review. Nutr Rev. 2004;62(5):177-203. https://doi.org/10. 1111/j.1753-4887.2004.tb00040.x

11. United States Department of Agriculture. A series of systematic reviews on the relationship between dietary patterns and health outcomes. Washington (DC): United States Department of Agriculture; 2014.

12. Nóbrega SM, Coutinho MPL. O teste de associação livre de palavras. In: Coutinho MPL, Lima AS, Oliveira FB, Fortunato $\mathrm{ML}$, organizadores. Representações sociais: abordagem multidisciplinar. João Pessoa: Universitária; 2003. p.67-77.

13. De Rosa AS. Le réseau d'associations: Une technique pour détecter La structure, les contenus, les indices de polarité, de neutralité et de stéréotypie du champ sémantique liés aux représentations sociales. In: Abric JC. Méthodes d'étude dês représentations sociales. Ramonville Saint-Agne: Érès; 2003. p.81-117.

14. Oliveira DC, Marques SC, Gomes AMT, Teixeira MCTV. A análise das evocações livres: uma técnica de análise estrutural das representações sociais. In: Moreira ASP, Camargo BV, Jesuíno JC, Nóbrega SM, organizadores. Perspectivas teórico-metodo-lógicas em representações sociais. João Pessoa: Universitária; 2005. p.573-99.

15. Oliveira T, Marquitti FD, Carvalhaes MABL, Sartorelli DS. Desenvolvimento de um Questionário Quantitativo de Frequência Alimentar (QQFA) para gestantes usuárias de unidades básicas de saúde de Ribeirão Preto, São Paulo, Brasil. Cad. Saúde Pública. 2010;26(12):2296-306.

16. Hearty AP, Gibney MJ. Comparison of cluster and principal component analysis techniques to derive dietary patterns in Irish adults. $\mathrm{Br} J$ Nutr. 2009;101(4):598-608. https://doi.org/10.1017/S0 007114508014128

17. Marchioni DML, Latorre MRDO, Eluf-Neto J, Wünsch-Filho $V$, Fisberg RM. Identification of dietary patterns using factor analysis in an epidemiological study in São Paulo. Sao Paulo Med J. 2005;123(3):124-7. https://doi.org/10.1590/S15 16-31802005000300007

18. Vilela AAF, Farias DR, Eshriqui I, Vaz JS, Franco-Sena $A B$, Castro MBT, et al. Prepregnancy Healthy Dietary Pattern Is Inversely Associated with Depressive Symptoms among Pregnant Brazilian Women. J Nutr. 2014;144(10):1612-18. https://doi.org/10. 3945/jn. 114.190488

19. Bouwland-Both MI, Steegers-Theunissen RPM, Vujkovic M, Lesaffre E, Mook-Kanamori D, Hofman A, et al. A periconceptional energy-rich dietary pattern is associated with early fetal growth: The Generation R study. Int J Obst Gynaecol. 2012;120(4):435-45. https://doi.org/10.1111/14 71-0528.12086

20. Hoffmann JF, Nunes MAA, Schmidt MI, Olinto MTA, Melere C, Ozcariz SGl, et al. Dietary patterns during pregnancy and the association with sociodemographic characteristics among women attending general practices in Southern Brazil: The ECCAGe Study. Cad Saúde Pública. 2013;29(5):970-80.

21. Instituto Brasileiro de Geografia e Estatística Pesquisas de Orçamentos Familiares (POF) 20082009: análise do consumo alimentar pessoal no Brasil. Brasília: IBGE; 2011 [acesso 2015 set 15]. Disponível em: http://186.228.51.37/home/ estatistica/populacao/condicaodevida/pof/ 2008_2009_medidas/pofmedidas.pdf 
22. Louzada MLC, Martins APB, Canella DS, Baraldil LG, Levy RB, Claro RM, et al. Ultra-processed foods and the nutritional dietary profile in Brazil. Rev Saúde Pública. 2015;49(38):1-11. https://doi.org/ 10.1590/S0034-8910.2015049006132

23. Brent RL, Christian MS, Diener RM. Evaluation of the reproductive and developmental risks of caffeine. Birth Defects Res B Dev Reprod Toxicol. 2011; 92(2):152-87. https//:doi.org/10.1002/bdrb. 2028

24. Northstone K, Emmett P, Rogers I. Dietary patterns in pregnancy and associations with demographic and lifestyle factors. Eur J Clin Nutr. 2008;62(1):471-9.

25. Cole ZA, Gale CR, Javaid MK, Robinson SM, Law C, Boucher BJ, et al. Maternal dietary patterns during pregnancy and childhood bone mass: A longitudinal study. J Bone Mineral Res. 2009;24(4):663-8. https://doi.org/10.1359/jbmr. 081212

26. Crozier SR, Robinson SM, Godfrey KM, Cooper C, Inskip HM. Women's dietary patterns change little from before to during pregnancy. J Nutr. 2009; 139(10):1956-63. https://doi.org/10.3945/jn.109. 109579

27. Hu FB. Dietary pattern analysis: A new direction in nutritional epidemiology. Curr Opin Lipidol. 2002;13(1):3-9.

28. Cotta RMM, Reis RS, Rodrigues JFC, Campos ACM, Costa GD, Sant'Ana LFR, et al. Aspectos relacionados aos hábitos e práticas alimentares de gestantes e mães de crianças menores de dois anos de idade: o programa saúde da família em pauta. Mundo Saúde. 2009;33(3):294-302.

29. Baião MR, Deslandes SF. Práticas alimentares na gravidez: um estudo com gestantes e puérperas de um complexo de favelas do Rio de Janeiro (RJ, Brasil). Ciênc Saúde Coletiva. 2010;15(2);3199-206. https://doi.org/10.1590/S1413-81232010000 80002
Received: December 15, 2015

Final version: September 19, 2016 Approved: November 11, 2016 
